\title{
Development of a Broad-Spectrum Antiviral Agent with Activity Against Herpesvirus Replication and Gene Expression
}

\author{
Wen-Jun Shi, Han-Xiao Sun*, Xue-Mei Mo, Shi-Yu Li, Xiu-Ying Li, Guang Zhang \\ and Hong-Ai Liu \\ Institute of Genomic Medicine, College of Pharmacy, Jinan University, Guangzhou, 510632, China
}

*For correspondence: Email: sunhanxiao5@gmail.com

\begin{abstract}
Purpose: To evaluate the broad-spectrum antiviral activity of peptide $\mathrm{H9}$ (H9) in vitro in order to gain insight into its underlying molecular mechanisms.

Method: Antiviral activity against Herpes simplex virus type 1 (HSV-1) was determined using thiazolyl blue (MTT) assay. Polymerase Chain Reaction (PCR) was employed to assay H9 antiviral activity against human cytomegalovirus (HCMV) and Epstein-Barr virus (EBV). The inhibitory effect of H9 on the replication of these viral genes including early genes was assayed by real time-Ppolymerase chain reaction (RT-PCR) and Western blot.

Results: H9 possessed significant inhibitory effect on the four different herpesviruses with $50 \%$ inhibitory concentration (IC $\mathrm{C}_{50}$ ) of $1.21 \mathrm{ng} / \mathrm{mL}$ (HSV-1). AD169 infection was strongly inhibited with an $E C_{50}$ value of $0.46 \mathrm{ng} / \mathrm{ml}$. The anti-herpesviral activity of $\mathrm{H} 9$ was dose-dependent. The peptide acted primarily during the early stage of infection by detection of the early genes.

Conclusion: The results demonstrate that H9 can inhibit the infection of HSV-1, EBV and HCMV. Furthermore, $\mathrm{H} 9$ has a broad-spectrum anti-herpesviral effect in vitro based on targeted killing of infected cells expressing genes.
\end{abstract}

Keywords: Antagonist, Trapping receptor/ligand, Broad-spectrum, Anti-herpesvirus, H9 peptide, Gene expression

Tropical Journal of Pharmaceutical Research is indexed by Science Citation Index (SciSearch), Scopus, International Pharmaceutical Abstract, Chemical Abstracts, Embase, Index Copernicus, EBSCO, African Index Medicus, JournalSeek, Journal Citation Reports/Science Edition, Directory of Open Access Journals (DOAJ), African Journal Online, Bioline International, Open-J-Gate and Pharmacy Abstracts

\section{INTRODUCTION}

In the last 20 years, herpesviruses have increased, leading to increase in the number of immunocompromised individals. Members of the herpesviridate families encode Viral G-proteincoupled receptors (vGPCRs) that mimic chemokines and chemokine receptors to evade the human immune system. vGPCRs make significant contributions to viral lifecycle and associate pathologies. As is already known, US28 encoded by human cytomegalovirus is the best investigation viral chemokine receptors.
US28 has been reported to form multiple signaling pathways via $G$ proteins, and various kinases are activated to regulate transcription factors such as nuclear factor $K B(N F K B)$ and activating protein 1 (AP1) [1-2].

In the foregoing cases, cellular signal pathways from vGPCR provide invaluable perspectives on virus-associated pathologies and may be hopeful drug targets that treat or prevent virus-associated pathologies. Latent infection of herpesvirus increases difficulties in treatment. Unfortunately, therapy approaches against herpesvirus with 
conventional anti-herpesvirus drugs have been mostly ineffective [3]. Currently, clinically antiherpesvirus drugs, in the form of nucleoside analogs, demonstrate significant effect in the therapy of herpesvirus. Several drugs, such as ganciclovir and cidofovir, are known to exhibit anti-herpesvirus activity during viral replication with normal molecular mechanisms in vitro by influencing gene expression [4,5]. However, drug resistance, development of drug-related toxicity and side effects limit their clinical use in patients $[3,6]$.

A critical feature of herpesvirus-mediated pathogenesis is the replication of the virus in infected tissue and the overt disease caused by viral replication [7]. For a productive infection, herpesvirus expresses three ordered classes of viral genes in a tightly regulated cascade, designated as immediate-early (IE), early (E) and late $(L)$, which are synthesized during infection [8]. On account of the fact that genes are essential for viral replication, it is imperative to research into herpesvirus pathogenesis, and as well as investigate the mechanisms of their regulation.

We had reported previously $[9,10]$ that the mechanism of $\mathrm{H} 9$ action on chemokine receptor US28 of human cytomegalovirus indicates antiviral activity against HCMV. The objective of the present study was to determine the ability of $\mathrm{H} 9$ to inhibit herpesviruses, EBV and HSV-1 genes required for viral DNA replication expression with a view to gaining insight into underlying molecular mechanisms.

\section{EXPERIMENTAL}

\section{Cells and viruses}

Vero cells and Helf cells were grown in Dulbecco's Modified Eagle's Medium supplemented with $10 \%$ fetal bovine serum (FBS). B95-8 cells and Raji cells were cultivated in RPMI 1640 with $10 \% \mathrm{v} / \mathrm{v}$ fetal calf serum (FCS). The infected Vero cells were overlaid with medium containing $1 \%$ of methylcellulose, and incubated for 3 days before it was fixed with formalin.

HCMV AD169 virus (5-10 $\mu \mathrm{l})$ was added to Helf cells at the concentration of $1 \times 10^{6} / \mathrm{ml}$ in logarithmic phase in logarithmic phase. Cytopathicity of cells was observed daily with inverted microscope (Olympus SZX16, Japan), and pp65 was monitored every 3 days. EBV production was induced chemically by the addition of 40nM TPA (phorbol 12-myristate 13acetate, Sigma) for 7 days and $3 \mathrm{mM}$ butyric acid for 3 days in medium containing $2 \%$ FCS.

\section{Cytotoxic assay}

$\mathrm{IC}_{50}$ was determined using MTT (Sigma-Aldrich) assay. Briefly, Vero cells was incubated in 96well plates $(100 \mu \mathrm{l}$ per well) . After a period of incubation, MTT solution $(0.15 \mathrm{~mL}, 5 \mathrm{mg} / \mathrm{mL}$ in $0.01 \mathrm{M}$ PBS) was added to each well. Subsequently, the cells were incubated for $4 \mathrm{~h}$ at $37{ }^{\circ} \mathrm{C}$ by removing MTT solution, then $100 \mu \mathrm{l} /$ well DMSO was added to each well, and the samples measured at $590 \mathrm{~nm}$ in a microplate reader.

\section{Evaluation of anti-EBV activity of $\mathrm{H} 9$}

Raji cells were incubated with or without $\mathrm{H} 9$ (from 0.01 to $100 \mathrm{ng} / \mathrm{ml}$ or $1000 \mathrm{ng} / \mathrm{ml}$ ) for $48 \mathrm{~h}$. Cell viability was determinded using MTT assay as previously prepared. A standard curve was constructed based on $\mathrm{H} 9$ concentration and \% cell survival.

\section{Real-time RT-PCT quantification of EBV mRNA}

The effect of $\mathrm{H} 9$ treatment on EBV on EBV of H9 treatment was determined by RT-PCR (Applied Biosystems). Simply, total RNA was prepared using TRizol reagent (Invitrogen). Reverse transcription was performed as follows: $11.5 \mu \mathrm{l}$ total RNA and $2 \mu$ Oligo(dT) ${ }_{15}$ were added to the tube. The mixture was heated to $70{ }^{\circ} \mathrm{C}$ for $5 \mathrm{~min}$ and quickly quickly to an ice bath for $5 \mathrm{~min}$. Thereafter, $4 \mu \mathrm{l} 5 \times \mathrm{RT}$ Reaction Buffer, $0.5 \mu \mathrm{l}$

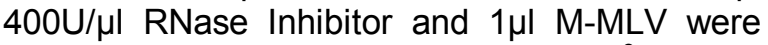
added. The tubes were incubated at $42{ }^{\circ} \mathrm{C}$ for 60 $\min$ and $95{ }^{\circ} \mathrm{C}$ for $10 \mathrm{~min}$. The primer pairs for BamH1-W were BamH1-WF (5'GCCAGAGGTAAGTGGACTTT-3') and BamH1WR (5'-TGGAGAGGTCAGGTTACTTA-3'); and for GAPDH were GAPDH-F (5'-AATCCCA TCACCATCTTCCA-3') and GAPDH-R (5'CCTGCTTCACCACCTTCTTG-3') [11]. The reaction mixture $(20 \mu \mathrm{l})$ contained $1 \mu \mathrm{l}$ of cDNA template, $2 \mu \mathrm{l}$ Taq Buffer and $1 \mu$ of each primer. Briefly, it was pre-incubated at $95{ }^{\circ} \mathrm{C}$ for $5 \mathrm{~min}$, followed by 30 cycles of $95^{\circ} \mathrm{C}$ for $30 \mathrm{~s}$, annealing at $59{ }^{\circ} \mathrm{C}$ for $30 \mathrm{~s}$, and polymerization at $72{ }^{\circ} \mathrm{C}$ for $30 \mathrm{~s}$, and a final extension of $7 \mathrm{~min}$ at $72{ }^{\circ} \mathrm{C}$ followed the last amplification cycle.

\section{Western blot detection of viral protein}

Monoclonal antibodies to the protein products of the EBV early genes have been described $[12,13]$. Anti-EBV antibodies to MAb-BALF2 (anti-EA; Chemicon, Temecula, CA) and PAbBZLF1 were used for analysis by standard Western blot technique [14]. Briefly, cell lysates were harvested in RIPA (radio immunoprecipitation assay) lysis buffer, and 
SDS-loading buffer added. The mixture was denatured at $95{ }^{\circ} \mathrm{C}$ for $10 \mathrm{~min}$. The lysates were separated $(15 \mu \mathrm{l})$ on $12.5 \%$ polyacrylamide gels followed by Western blot transfer and immunostaining with EBV specific antibodies [15].

\section{Evaluation of anti-HCMV activity of $\mathrm{H} 9$}

Helf cells were cultivated on 24-well plates and used for infection with AD-169 HCMV and counted for the number of syncytial cytopathic effects (CPEs). CPE inhibitory rate and $\mathrm{EC}_{50}$ (50 $\%$ effective concentration) were calculated according to Reed-Muench method [16]. H9 were added either after virus adsorption (post) or preincubation of the cells for $1 \mathrm{~h}$.

The UL83 sequence encoding pp65 was isolated by PCR with primers specific for pp65 5'GTCAGCGTTCGTGTTTCCCA-3' and 5'GGGACACAACACCGTAAAGC-3'. For qPCR, a FAM-TAMRA-labeled TaqMan probe was used. qPCR was performed on a ABI 7300 sequence detection system using SYBR Green Kit (Invitrogen) under the following conditions: $2 \mathrm{~min}$ at $50{ }^{\circ} \mathrm{C}, 3 \mathrm{~min}$ at $95{ }^{\circ} \mathrm{C}$, followed by 10 cycles of $45 \mathrm{~s}$ at $95{ }^{\circ} \mathrm{C}$ and $55 \mathrm{~s}$ at $60^{\circ} \mathrm{C}$. Inhibitory rate was calculated as $\{(A-B) /(A) \times 100\}$, where $A$ and $B$ denote the copy number of HCMV control group and $\mathrm{H} 9$ control group, respectively.

\section{Assessment of anti-HSV-1 activity of $\mathrm{H} 9$}

Vero cells were incubated in 96-well plates (100 $\mu \mathrm{l}$ per well). After a period of incubation, cell viability was determined using MTT assay as previously described. A standard curve was constructed based on $\mathrm{H} 9$ concentration and \% cell survival. $I_{50}$ (50\% effective concentration) was determined by Reed-Muench method [16].

\section{RT-PCR of HSV-1 genes}

The effect of H9 on IE(UL54), E(UL30) and L(US6) genes from HSV of $\mathrm{H} 9$ treatment was determined by RT-PCR method. Simply, total RNA was prepared using TRizol reagent (Invitrogen). Reverse transcription was performed as described above. Primers and probes were added as outlined in Table 1.The reaction mixture $(20 \mu \mathrm{l})$ contained $1 \mu \mathrm{l}$ of cDNA template, $2 \mu \mathrm{l}$ Taq Buffer and $1 \mu \mathrm{l}$ of each primer. Briefly, it was pre-incubation at $95{ }^{\circ} \mathrm{C}$ for $5 \mathrm{~min}$, followed by 30 cycles of $95^{\circ} \mathrm{C}$ for $30 \mathrm{~s}$, annealing at $59{ }^{\circ} \mathrm{C}$ for $30 \mathrm{~s}$, and polymerization at $72{ }^{\circ} \mathrm{C}$ for $30 \mathrm{~s}$, followed by a final extension at $72{ }^{\circ} \mathrm{C}$ for 7 $\min$.
Table 1: Primers and probes used in the multiplex real-time PCRs specific to the polymerase gene of HSV-1

\begin{tabular}{|c|c|c|}
\hline Gene & Primers Sequence (5'-3') & $\begin{array}{l}\text { Amplicon } \\
\text { size (bp) }\end{array}$ \\
\hline UL54 & $\begin{array}{l}\text { 5'- } \\
\text { CCAGGACCCTATCATCGGAACG- } \\
3^{\prime} \\
\text { 5'- } \\
\text { AGTATTTCAATGAGACCCGCCAT- } \\
\text { 3' }\end{array}$ & 303 \\
\hline UL30 & $\begin{array}{l}\text { 5'- } \\
\text { GAAGCGCAGCAAGATAAAGG-3' } \\
\text { 5'- } \\
\text { ATGGTQCGGGTGATGTTAAT-3' }\end{array}$ & 309 \\
\hline US6 & $\begin{array}{l}\text { 5'- } \\
\text { GGTTTACTACGCCGTGTTGG-3' } \\
\text { 5'- } \\
\text { ATCTTCACGAGCCGCAGGTA-3' }\end{array}$ & 342 \\
\hline GAPDH & $\begin{array}{l}\text { 5'- } \\
\text { AATCCCATCACCATCTTCCA-3' } \\
\text { 5'- } \\
\text { CCTGCTTCACCACСTTCTTG-3' }\end{array}$ & 580 \\
\hline
\end{tabular}

\section{Statistical analysis}

The results were presented as mean \pm standard deviation. The data were analyzed by SPSS software, version 16. Significant differences $(p<$ 0.01 ) between groups were determined using unpaired Student's t-test.

\section{RESULTS}

\section{Cytotoxic and optimum drug concentrations}

H9 were examined for cytotoxicity to Vero cells and for detection of drug concentration screening using Raji cells by MTT assay. Fifty percent toxic concentration $\left(\mathrm{TC}_{50}\right)$ of $\mathrm{H} 9$ was $>1000 \mathrm{ng} / \mathrm{ml}$. To investigate the optimum drug concentrations for RT-PCR studies, Raji cells were incubated with $\mathrm{H} 9$ from $0.01 \mathrm{ng} / \mathrm{ml}$ to $1000 \mathrm{ng} / \mathrm{ml}$. The data are shown in Fig 1.

\section{Inbibitory effect of H9 on EBV RNA expression}

Fig $2 \mathrm{~A}$ reveal that the levels of EBV RNA decreased with elevation of $\mathrm{H} 9$ concentration, unlike the control group $(p<0.05)$.

\section{Inbibitory effect of $\mathrm{H} 9$ on viral proteins}

Fig 2B shows that the levels of early viral proteins decreased with increase in $\mathrm{H} 9$ dose, unlike the control group $(p<0.05)$. It also revealed that anti-EBV protein activity of $\mathrm{H} 9$ was dose-dependent. 


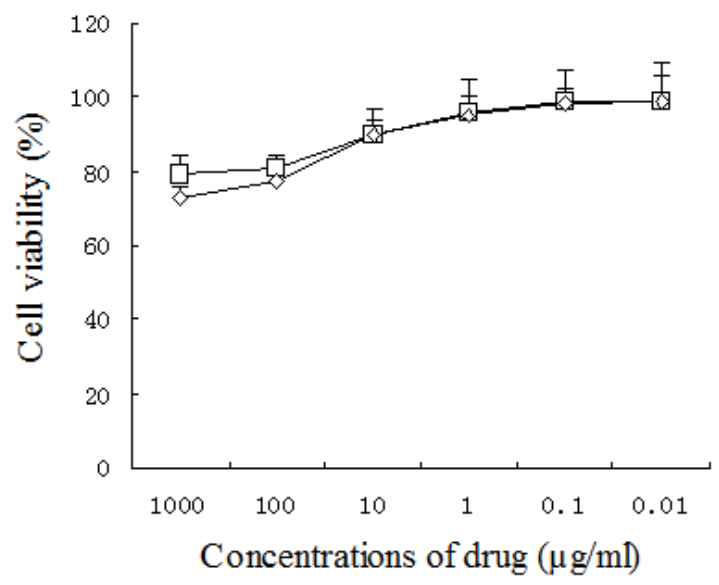

Figures 1: Cytotoxicity $(\diamond)$ and drug concentration ( $\square$ ) of $\mathrm{H} 9$ based on Vero and Raji cells.
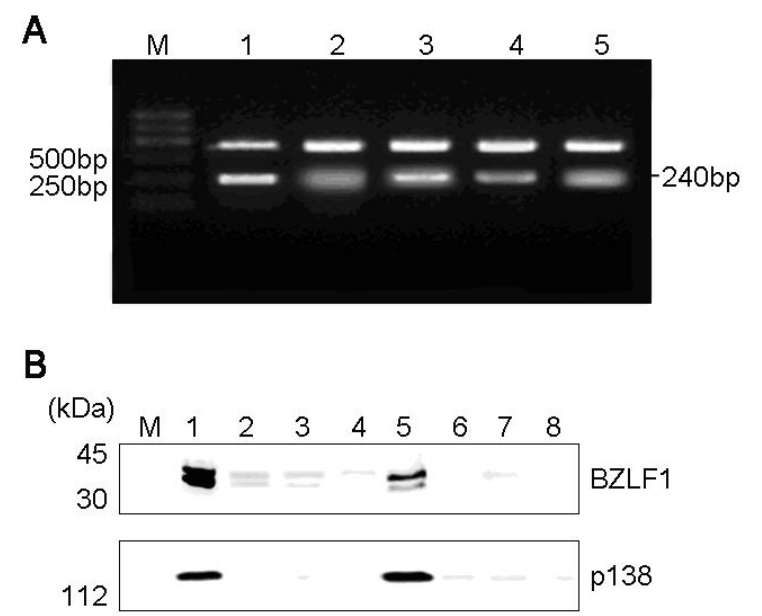

Figure 2: Effect of $\mathrm{H} 9$ on (A) EBV DNA replication (M $=$ Marker; $1=\mathrm{EB}$ virus; $2=\mathrm{ACV} ; 3=1 \mathrm{ng} / \mathrm{mL} \mathrm{H9} ; 4=$ $5 \mathrm{ng} / \mathrm{mL} \mathrm{H9} ; 5=10 \mathrm{ng} / \mathrm{mL} \mathrm{H9}$ ), and (B) the levels of EBV viral immediate early protein and early protein (M $=$ Marker; $1=\mathrm{EB}$ virus, $48 \mathrm{~h} ; 2=\mathrm{ACV}, 48 \mathrm{~h} ; 3=5$ $\mathrm{ng} / \mathrm{mL} \mathrm{H9}, 48 \mathrm{~h} ; 4=10 \mathrm{ng} / \mathrm{mL} \mathrm{H9}, 48 \mathrm{~h} ; 5=\mathrm{EB}$ virus, $72 \mathrm{~h} ; 6=\mathrm{ACV}, 72 \mathrm{~h} ; 7.5 \mathrm{ng} / \mathrm{mL} \mathrm{H}$, $72 \mathrm{~h} ; 8.10 \mathrm{ng} / \mathrm{mL}$ $\mathrm{H} 9,72 \mathrm{~h})$

\section{Anti-HCMV activity}

H9 inhibited the production of pp65 in HCMVinfected Helf cell culture supernatant in a dose-dependent manner. $\mathrm{EC}_{50}$ of $\mathrm{H} 9(0.46 \mathrm{ng} / \mathrm{ml})$ was greater than that of the standard ganciclovir (GCV) group $(0.68 \mathrm{ng} / \mathrm{ml})$. As shown in Fig $3 A$, with increasing dose of $\mathrm{H} 9$, the numbers of helf cells treated with $\mathrm{H} 9$ gradually increased. Furthermore cytotoxicity was low.

With regard to the inhibitory effect of HCMV, Fig 3B shows that HCMV infection rate had no significant effect $(p<0.05)$ at 24 and $48 \mathrm{~h}$, compared with control group. However, after 72 h, H9 inhibited HCMV spreading in helf cells in a dose-dependent fashion, and reach a peak value of $60 \%$ at $10 \mathrm{ng} / \mathrm{mL}$.

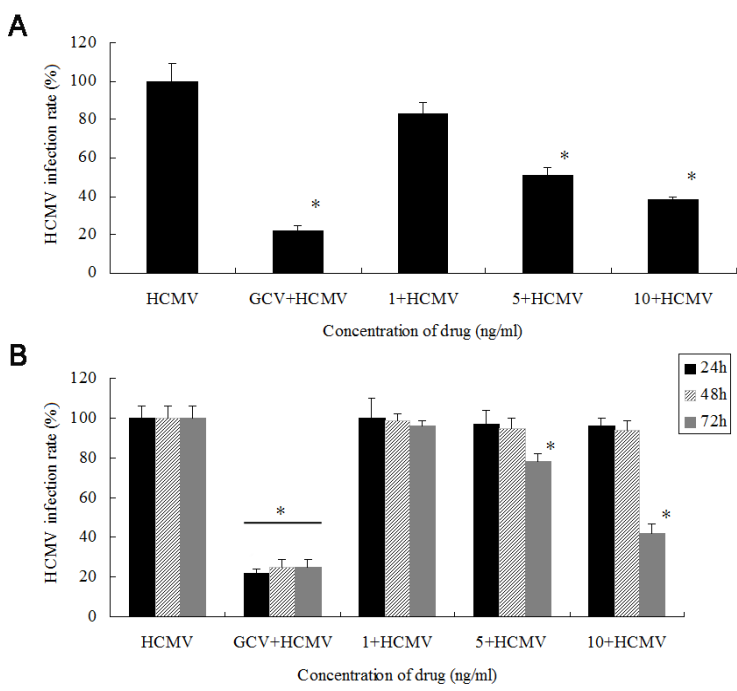

Figure 3: Effect of $\mathrm{H} 9$ on HCMV replication $(\mathrm{A})$ and diffusion $(\mathrm{B}) ;{ }^{*} p<0.05$ compared with control

\section{Anti-HSV-1 activity}

As shown in Fig 4A, It is noteworthy that HSV-1 virus was effectively inhibited by $\mathrm{H} 9$ at 1.25 $\mathrm{ng} / \mathrm{ml}$.

\section{Inhibitory effect on HSV-1 genes replication}

To determine if there was decrease in gene expression, we examined changes in steadystate gene mRNA level by RT-PCR. As shown in Fig 4, B-E, ACV and H9 $(10 \mathrm{ng} / \mathrm{mL})$ significantly $(p<0.05, p<0.01)$ decreased and delayed UL54, UL30 and US6 mRNA expression. Mocktreated control cells exhibited normal levels of UL54, UL30 and US6 mRNA expression. Primers specific for GAPDH were used to confirm that equal amounts of cDNA were used in each PCR.

\section{DISCUSSION}

Several parts of the chemokine system have been hijacked and wrecked by herpesviruses, including ligands and the receptors. vGPCRs are important for herpesviruses during viral life cycle to display different healing mechanisms. In a previous study, it was observed that there were significant differences in absorbance between H9-treatment and negative BSA-treatment groups, which is strongly suggests that $\mathrm{H} 9$ interacts with the US28 receptor. Moreover, after interaction with US28 receptor, the level of $\mathrm{Ca}^{2+}$ concentration induced by hMIP-1 $\beta$ could be efficiently prevented by $\mathrm{H} 9$, which further demonstrates that $\mathrm{H} 9$ is an effective antagonist of US28 $[9,10]$. These results suggested that 
anti-HCMV mechanism of $\mathrm{H} 9$ seems to involve binding initially with HCMV membrane.

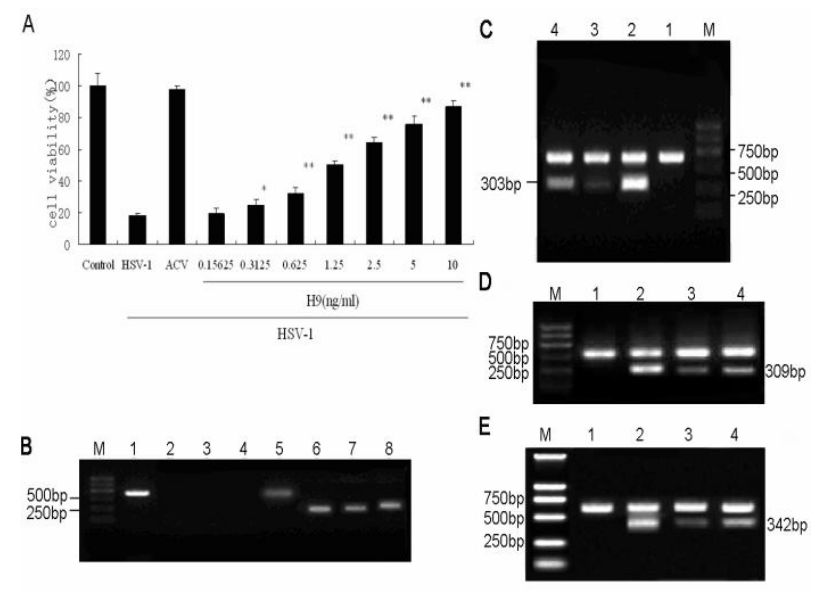

Figures 4: Effect of $\mathrm{H} 9$ on HSV-1; (A) inhibitory effect of $\mathrm{H} 9$ on MTT; (B) expression of target genes in normal cells and cells infected by HSV $-1(\mathrm{M}=$ marker; lanes $1-4=$ normal Vero cells $(1=$ GAPDH; $2=$ UL54; 3 = UL30; 4 = US6; lane $5-8=$ HSV group; 5 = GAPDH, 6UL54; 7 = UL30; 8 = US6); (C) effect of H9 on specific expression of HSV-1 UL54 mRNA (M = Marker; 1 = Vero cells; 2 = HSV-1; 3 = ACV; 4 = H9); (D) effect of H9 on specific expression of HSV-1 UL30 mRNA (M = Marker; 1 = Vero cells; 2 + HSV-1; 3 = ACV; 4 = H9); (E) effect of $\mathrm{H9}$ on specific expression of HSV-1 US6 mRNA (M = marker; 1 = Vero cells; 2 = HSV $-1 ; 3=\mathrm{ACV} ; 4=\mathrm{H} 9) ;{ }^{*} p<0.05,{ }^{* *} \mathrm{p}<0.01$ compared with control

Like ORF74 and BILF1, US28 displays constitutive signaling pathway through Gai and Gaq as well as NFAT by CREB, which is important for the expression of viral genome, and specifically by stimulating immediate-early gene promoter[1, 17,18]. We hypothesize that $\mathrm{H} 9$ changed cellular signaling to influence the level of gene expression specifically, including early gene, by interferring with vGPCRs, resulting in inhibition of viral replication.

Small molecular peptides are widely expressed and gradually become the research focus. US28 receptor is highly homologous to many receptors encoded by viruses such as ORF74 and U12, which can interact with a wide variety of human chemokines, such as CC and CX3C chemokine. The initial purpose of the present study on the screening was to develop a small peptide acting as a broad spectrum chemokine antagonist, which combines with various chemokine receptors, and compare it with some small peptides that interact with human receptors.

We had studied on acting as a broad spectrum chemokine antagonist, $\mathrm{H} 9$, which combines with various chemokine receptors, and displays inhibitory activity against various herpesviruses.
The experimental results showed that $\mathrm{H} 9$ possessed significant inhibitory effects on the three different herpesviruses. Inhibitory concentration $\left(\mathrm{IC}_{50}\right)$ values was $1.21 \mathrm{ng} / \mathrm{mL}$ (HSV-1). AD169 infection was strongly inhibited with an $\mathrm{EC}_{50}$ value of $0.46 \mathrm{ng} / \mathrm{ml}$.

During virus infection and pathogenicity, viral replication plays a key role, and viral replication suppression is a critical feature to exploit novel drug. To gain insight into the underlying molecular mechanisms, we analyzed the ability of $\mathrm{H} 9$ to inhibit EBV viral DNA replication and gene expression by EBV protein-specific Western blots. This was confirmed by results obtained by detection of viral genomes by RTPCR, and they indicated suppression of viral genome replication with an intermediate concentration of $\mathrm{H} 9$ (10 ng/mL). BILF1 encoded by EBV mainly take part in immune escape and inhibits the phosphorylation of RNA-dependent protein kinase (PKR) to help EBV by preventing acellular antiviral response [19]. vGPCRs displays constitutive signaling that is important for the regulation of viral genome, specifically by stimulating immediate-early gene promoter in vitro from infection cell. A major immediate-early promoter (MIEP) regulated IE gene expression and required productive viral replication as well as immediately early (IE) gene transcription [20]. Like anti-EBV activity, H9 could downregulate the transcriptional expression of UL54, UL30 and US6, resulting in the inhibition HSV-1 infection. Based on these findings, it is proposed that $\mathrm{H} 9$ changes vGPCRs cellular pathway, like NF-KB activity, and thus causes efficient replicative block at the level of viral gene expression, including specifically early gene, by interferring with vGPCRs (Fig 5). All of these results indicate that $\mathrm{H} 9$ may be a broad-spectrum therapeutic antagonist for herpesviruses.

\section{CONCLUSION}

H9 inhibited the infection of herpes simplex virus type 1 (HSV-1), Epstein-Barr virus (EBV) and human cytomegalovirus (HCMV), and demonstrated a broad-spectrum anti-herpesvirus effect in vitro. At the same time, the level of immediate-early gene expression was decreased, resulting in the inhibition of viral replication. These results demonstrate that $\mathrm{H} 9$ is an efficient broad-spectrum antiviral agent with activity against herpesvirus replication and genes expression including early genes. 


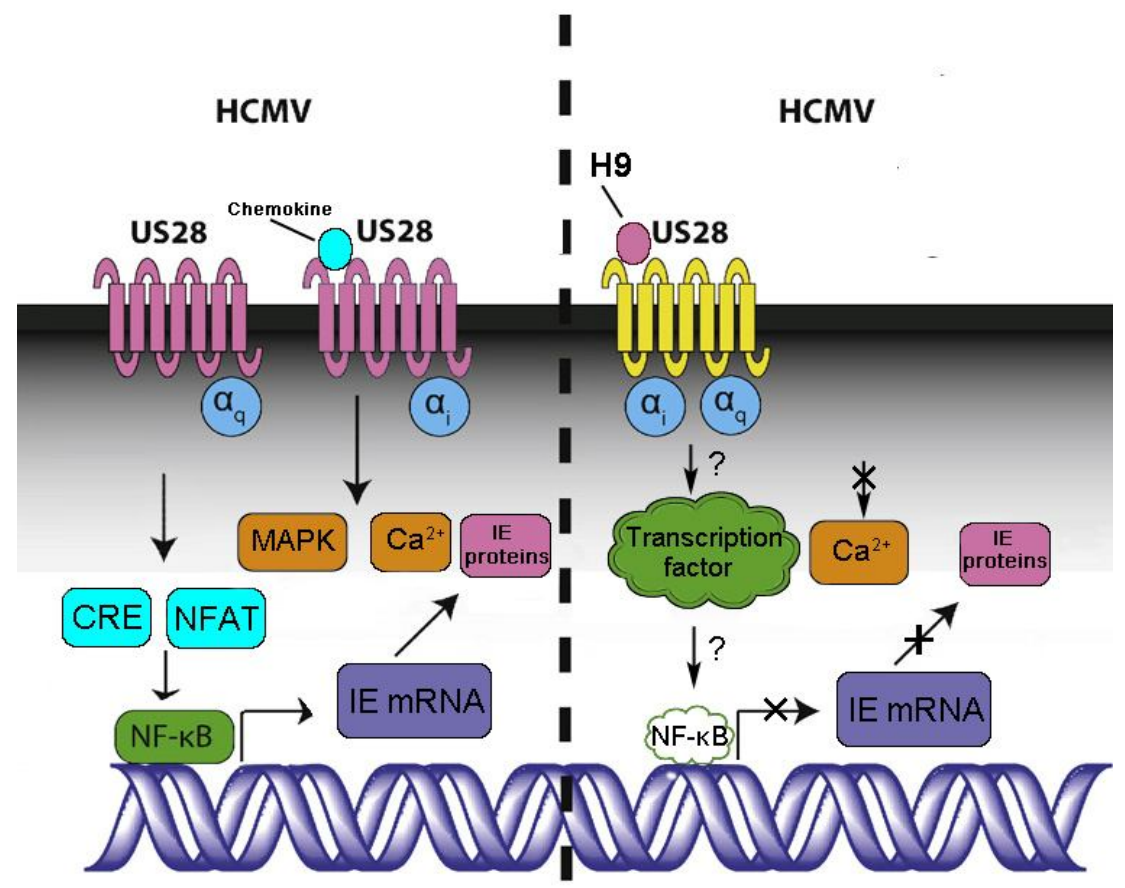

Major immediate-early promoter

Figures 5: Schematic illustration of the effect of US28 cellular signaling without or with H9 treatment, in vitro. From left to right: US28 displays constitutive signaling manner through Gai and Gaq as well as NFAT by CREB which is important for the expression of the viral genome, specifically by stimulating the immediate-early gene promoter. H9 peptide may change cellular signaling to influence the level of immediate-early gene expression by interfered with vGPCRs, resulting in the inhibition of viral replication (Illustration is adapted from Slinger et al [21]).

\section{ACKNOWLEDGEMENT}

This study was supported by the National Science Foundation of China (NSFC, no.3087221), Guangdong Province Major Projects of Key Areas (YS No, 2005/162), and major technology program funded projects, Guangzhou (2011Y1-00017-3).

\section{REFERENCES}

1 Casarosa $P$, Bakker RA, Verzij D, Navis M, Timmerman $H$, Leurs $R$, Smit MJ. Constitutive signaling of the human cytomegalovirus-encoded chemokine receptor US28. J Bio Chem 2001; 276: 1133-1137.

2 Marcos GG, Alexandre MP, Kristian KJ, PokMan C, Stuart $C S$, Sergio $A$ L. The human herpesvirus 8 chemokine receptor $v G P C R$ triggers autonomous proliferation of endothelial cells. J Clin Invest 2006, 116: 1264-1273.

3 Billaud G, Thouvenot D, \& Morfin F, Drug targets in herpes simplex and Epstein Barr Virus infections, Infects Disords-Drug Targets, 2009; 9: 117-125.

4 Hitchcock MJM, Jaffe HS, Martin JC, Stagg RJ. Cidovir, a new agent with potent anti-herpesvirus activity. Antimicrob Agents Ch 1996; 7: 115-127.

5 Coen DM, Schaffer PA. Antiherpesvirus drugs: a promising spectrum of new drugs and drug targets. Nat. Rev. Drug Discov 2003; 2: 278-288.

6 Frobert E, Cortay JC, Ooka T, Najioullah F, Thouvenot D, Lina B, Morfin F. Genotypic detection of acyclovirresistant HSV-1: characterization of 67ACV- sensitive and 14 ACV-resistant viruses. Antiviral Res 2008; 79: 28-36.

7 DeMeritt IB, Milford LE, Yurochko AD. Activation of the NFkB Pathway in Human Cytomegalovirus-Infected Cells Is Necessary for Efficient Transactivation of the Major Immediate-Early Promoter. J Virol 2004; 78: 4498-4507.

8 Honess RW, Roizman B. Regulation of herpesvirus macromolecularsynthesis $I$. Cascade regulation of synthesis of three groups of viral proteins. J Virol 1974: 14: 8-19.

9 Liu H, Sun HX, Mo XM, Li SY, Li XY, Zhang G, Li L. Anti$H C M V$ and KSHV effect of a trapping ligand antagonist for Herpesvirus-encoded GPCR. Indian $J$ Exp Bio. 2012; 50: 313-319.

10 Liu H, Sun HX, Li L, Mo XM, Li XY, Zhang G. Screening and Mechanism of Trapping Ligand Antagonist Peptide for Chemokine Receptor US28 of Human Cytomegalovirus. Trop J Pharm Res 2012; 11: 193-200.

11 Chiou SH, Chow KC, Yang $\mathrm{CH}$, Chiang SF, Lin $\mathrm{CH}$. Discovery of Epstein-Barr virus (EBV)-encoded $R N A$ signal and EBV nuclear antigen leader protein DNA sequence in pet dogs. J Gen Virol 2005; 86: 899-905.

12 Marschall $M$, Stein-Gerlach $M$, Freitag $M$, Kupfer $R$, van den Bogaard $M$, Stamminger T. Inhibitors of human cytomegalovirus replication drastically reduce the activity of the viral protein kinase pUL97. J Gen Virol 2001; 82: 1439-1450.

13 Rechter S, König T, Auerochs S, Thulke S, Dörnenburg $H$, Walter C, Marschall M. Antiviral activity of Arthrospira-derived spirulan-like substances. Antiviral Res 2006; 7: 197-206.

14 Marschall $M$, Leser $U$, Seibl $R$, Wolf $H$. Identification of proteins encoded by Epstein-Barr viral transactivator genes. J Virol 1989; 63: 938-942. 
15 Auerochs S, Korn K, Marschall M. A reporter system for Epstein-Barr virus (EBV) lytic replication:Anti-EBV activity of the broad anti-herpesviral drug artesunate. J Virological Methods 2011; 173: 334339.

16 Boshoff C, Endo Y, Collins PD, Takeuchi Y, Reeves JD, Schweickart VL, Siani MA, Sasaki TJ, Gray PW, Moore PS, Chang Y, Weiss RA. Angiogenic and HIV-inhibitory functions of KSHV-encoded chemokines. Science 1997; 278: 290-294.

17 McLean KA, Holst PJ, Martini L, Schwartz TW, Rosenkilde MM. Similar activation of signal transduction pathways by the herpesvirus-encoded chemokine receptors US28 and ORF74. Virology 2004: 325: 241-251.

18 Wen $D Q$, Zhang $Y Y$, Lv LP, Zhou XP, Yan F, Ma $P, X u$ $J B$. Human cytomegalovirus-encoded chemokine receptor homolog US28 stimulates the major immediate early gene promoter/enhancer via the induction of CREB. J Recept Signal Transduct Res 2009; 29: 266-273.

19 Beisser PS, Verzijl D, Gruijthuijsen YK, Beuken E, Smit MJ, Leurs R, Bruggeman CA, Vink C. The EpsteinBarr virus BILF1 gene encodes a Gprotein-coupled receptor that inhibits phosphorylation of RNAdependent protein kinase. J Virol 2005; 79: 441449.

20 Isomura H, Stinski MF. The human cytomegalovirus major immediate-early enhancer determines the efficiency of immediate-early gene transcription and viral replication in permissive cells at low multiplicity of infection. J Virol 2003; 77: 36023614.

21. Slinger $E$, Langemeijer $E$, Siderius $M$, Vischer HF, Smit MJ. Herpesvirus-encoded GPCRs rewire cellular signaling. Mol Cell Endocrinol 2011; 331: 179-184. 